\title{
Development of Oral Disintegration Film Containing Naturally Derived Compounds Using Peptide Collagen and a Study of its Functions
}

Dong-Sub Kim, In-Jun Han , Byung Soo Lee, Sang-Yun Park, Eun Yeong Nho, Ji Eom, Ji Young Suh, Geon Kim, Jihyun Park, Nak-Yun Sung Division of Natural Product Research, Korea Prime Pharmacy CO., LTD., Gwangju, Korea

*Corresponding author: Nak-Yun Sung, Division of Natural Product Research, Korea Prime Pharmacy CO., LTD., 211 Jungang-ro, Dong-gu, Gwangju 61473, Korea

Tel.: +82 3180256902

Fax: +82 318886699

Email: ny.sung@koreaprime.co.kr

Received May 07, 2020

Revised May 18, 2020

Accepted May 25, 2020

Published June 30, 2020

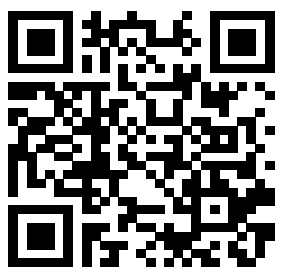

\begin{abstract}
Purpose: In this study, we aim to study the functionality of multiple effects of peptide collagen and naturally derived compounds through in vitro experiments and human application tests. Method: Cytotoxicity of inner beauty film (IBF), pro-collagen generation ability, elastase and collagenase inhibition, DPPH radical scavenging and tyrosinase inhibition ability were measured, and skin improvement, through in vitro and human application test. Results: Cytotoxicity was not confirmed up to $1000 \mu \mathrm{g} / \mathrm{mL}$. Elastase inhibition was $7.2 \%$ at a concentration of $125 \mu \mathrm{g} / \mathrm{mL}$, and collagenase showed an inhibition rate of $16.3 \%$ at $31.3 \mu \mathrm{g} / \mathrm{mL}$. The pro-collagen synthesis showed expression of $34 \%$, compared with the negative control when the concentration was $62.5 \mu \mathrm{g} / \mathrm{mL}$. The antioxidant activity of $250 \mu \mathrm{g} / \mathrm{mL}$ and whitening effect of $62.5 \mu \mathrm{g} / \mathrm{mL}$ are showed in the Results section, and there was no observed deformation or color change even after confirming the stability for 6 months. Even in the human clinical study, the wrinkle improvement before and after using the IBF was $32.2 \%$ at maximum, skin melanin and brown spot improvement was $32.5 \%$, pore improvement was $31.5 \%$, and skin density improvement was $12.8 \%$, as shown in the Results section. Conclusion: Therefore, the IBF containing the complex of peptide collagen and naturally derived compounds has a positive effect on wrinkle improvement, skin melanin and brown spot improvement, skin pore improvement, and skin density improvement, as well as exhibiting antioxidant and whitening effects. As a result, IBF can be developed as a key material for cosmetics and foods.
\end{abstract}

Keywords: Inner beauty film, Wrinkle improvement, Whitening, Functional cosmetics, Peptide collagen

\section{Introduction}

피부는 노화가 진행됨에 따라 각질형성세포, 진피세포, 멜라닌 세포, 땀샘 등의 기능이 저해되며 주름이 생기고 탄력성을 잃어 가 게 된다. 나이, 자외선 등의 많은 내외적인 스트레스 요인 때문에 피 부의 탄력과 촉촉함이 사라지고 주름이 생기게 된다. 피부의 신진 대사 저하 및 세포 수 및 세포간 물질 등의 감소에 따라 피부 속 공 간이 생기고 그 공간으로 골이 생겨 주름 형태로 나타나게 된다. 따 라서 피부주름을 예방하기 위해선 피부 보습력을 증가시키고 외부 의 자극으로부터 보호해야 하며 피부세포를 활성화 시켜 콜라겐, 엘 라스틴 등의 생체단백질 합성 촉진을 유도해야 한다(Waller et al.,
2006; Skobe et al., 2000). 피부주름과 탄력 구성에 중요한 역할을 하는 콜라겐은 노화에 따라 생성율이 떨어지고 분해율이 높아져 콜 라겐의 감소는 주름의 증가로 이어진다. 이러한 현상을 늦추거나 주 름을 감소시키기 위해 최근 향장기능성 소재들을 이용하여 예방하 고 외부 자극으로부터 보호하거나 생체 내 단백질 합성을 촉진되는 연구들이 점점 많아지고 있다(Kang, 1997). 이러한 콜라겐을 이용 한 피부표면 흡수 제품이 많이 나왔으나 최근 연구결과에 콜라겐의 피부표면흡수는 고분자 콜라겐의 흡수율이 효율적이지 못하다는 의 견도 많아 지고 있다(Choi et al., 2014; Zhang et al., 2020). 효과 적인 섭취방법을 내세운 먹는 콜라겐의 수요가 높아지고 있으나 콜 라겐 구조의 체내 흡수에 대해서는 아직까지 많은 부분 알려져 있지 
않고 있다(Ichikawa et al., 2010; Kim et al., 2011). 하지만 최근 구강점막세포를 통한 콜라겐의 흡수가 장내 소화를 통한 흡수보다 빠르다고 연구 되었으며 분자량의 크기에 영향이 적어 고분자 콜라 겐도 빠르게 흡수시킬 수 있다고 보고 되었다(Takenokuchi et al., 2018). 하지만 기존 선행연구에서는 채내 콜라겐의 흡수율이 저분 자에 가까울수록 효율이 늘어나는 것으로 연구된 보고가 많음에도 불구하고 콜라겐의 인체 내 흡수에 대한 자세한 연구는 많이 되어 있지 않다(Chai et al., 2010).

본 연구에서는 연구자의 선행연구에서 제시된 비타민 나무, 블랙 베리, 약용들깨 추출물 최적배합비를 통한 천연추출복합물의 주름 개선, 항산화, 함염, 미백, 산화적스트레스에 의한 세포 손상 억제 등의 기능성을 갖는 천연추출복합물과 3,000 Dalton 이하의 저분 자 콜라겐을 혼합으로 사용하여 인체 내 콜라겐 및 천연추출복합물 의 흡수에 따른 영향을 in vitro 실험과 인체적용시험을 통하여 알아 보고자 한다(Chai et al., 2010; Kim et al,. 2019). 간단히 말하면, 체내 흡수율을 높인 저분자 콜라겐과 천연추출복합물을 혼합하여 체내 콜라겐의 흡수율을 높이고 천연추출복합물 기능성을 추가하여 손쉽게 섭취 할 수 있는 oral disintegrating film (ODF) 제형을 도 입한 이너뷰티필름(inner beauty film, $\mathrm{IBF}$ ) 개발품에 대한 기능성 검증과 안정성에 대해 연구 하고자 한다.

\section{Materials \& Methods}

\section{1. 시료 준비}

구입한 천연물질(비타민나무, 블랙베리, 약용들깨)은 각각 500 $\mathrm{g}$ 씩 용기에 담아 열에 의한 손상을 피하기 위해 $60^{\circ} \mathrm{C}$ 에서 5 일 동 안 건조하였다(Larrauri et al., 1997). 건조한 천연물질은 분쇄기 (HM-2100S; Hanilelec, Korea)로 처리하여 50 mesh의 체를 통 과한 미세입자를 선별하였다. 분쇄한 각각의 재료 $10 \mathrm{~g}$ 을 유리병에 넣고 3차 증류수를 채워 최종적으로 $100 \mathrm{~mL}$ 가 되게 한 후 밀폐한 상태에서 $200 \mathrm{rpm}$ 으로 $30 \mathrm{~min}$ 동안 교반기(MSH-20A; Daihan, Korea)를 이용하여 현탁액을 만들고 $4^{\circ} \mathrm{C}$ 의 냉장고에 넣어 $48 \mathrm{~h}$ 동 안 저온 숙성하였다. 이 후 원심분리기(UNION32R plus; Hanil Scientific, Korea)를 이용하여 $4^{\circ} \mathrm{C}$ 에서 $5,000 \mathrm{rpm}$ (원심력: 3,000 $\times \mathrm{g}$ )으로 $90 \mathrm{~min}$ 동안 침전물을 제거하고 투명한 상등액을 분리하 였다. 각 재료의 추출물은 선행연구의 최적배합비에 따라 배합되어 분석대상 표준물질의 표준곡선 범위에 맞추어 희석하여 사용하였 다. 식품첨가물 및 필름제형의 원료는 ES식품원료로부터 구매하여 사용였으며 콜라겐은 어린(魚鱗)으로부터 추출된 저분자 콜라겐으 로 Geltech (Korea)에서 식품원료로 구매하여 사용하였다.

\section{2. 천연추출복합물을 이용한 필름제형 제조}

천연추출복합물 소재와 필름제형(풀루란, 변성전분; ES Food,
Korea)을 교반기(T.K. HIVIS Disper Mix, Model 3D-2; PRIMIX, Japan)에 넣고 $20 / 1500 \mathrm{rpm}$ 으로 동시에 $30 \mathrm{~min} 70^{\circ} \mathrm{C}$ 에서 균질화하 고 이후 점증제(카라기난, 폴리아크릴산나트륨)를 첨가하고 20/2500 $\mathrm{rpm}$ 으로 $30 \mathrm{~min} 70^{\circ} \mathrm{C}$ 에서 균질화 하였다(Jeong et al., 2019). 이 후 필름 혼합액을 상온에서 $1 \mathrm{~h}$ 동안 냉각한 후, 글리세린 및 첨가제 (Collagen, Geltech)를 넣어 $20 \mathrm{rpm}$ 으로 $10 \mathrm{~min}$ 간 교반 후 필름 용 액을 교반기에 연결된 진공펌프를 이용하여 $-0.092 \mathrm{MPa}$ 조건으로 탈기하여 기포를 제거한 후 teflon 플레이트가 올려져 있는 필름코터 (MSK-AFA-III; MTI, USA)에 옮겨 $30^{\circ} \mathrm{C}, 15 \mathrm{~h}$ 조건으로 건조시켜 최종 수분함량이 $10 \% \pm 2$ 가 되도록 필름을 제조하였으며 in vitro 실 험에서는 다시 해당 농도별로 $\mathrm{PBS}$ 에 녹여 희석 배수에 따른 농도를 산정하여 실험에 사용하였다.

\section{3. 세포주 및 세포배양}

사람의 피부각질형성세포인 $\mathrm{HaCaT}$ 세포와 진피섬유아세포 (human dermal fibroblast, HDF)는 한국세포주은행(Korean Cell Line Bank, KCLB)에서 분양 받아 10\% fetal bovine serum (FBS; Gibco BRL, USA)과 1\% Penicillin-Streptomycin Solution (P/S)을 첨가한 Dulbecco's Modified Eagle's Medium (DMEM; Gibco BRL) 배지에 $37^{\circ} \mathrm{C}, 5 \% \mathrm{CO}_{2}$ 조건에서 배양하였다. 세포 배양배지는 세포가 $80 \%$ 이상 자란 시점에서 2-3일마다 교환하였다.

\section{MTT assay}

천연추출복합물의 함량과 이너뷰티필름의 세포독성을 확인하 기 위해 $\mathrm{HaCaT}$ 세포와 $\mathrm{HDF}$ 세포를 96 well plate에 $3 \times 10^{4}$ cell/ well 의 농도로 분주한 후 $37^{\circ} \mathrm{C}, 5 \% \mathrm{CO}_{2}$ incubator에서 $24 \mathrm{~h}$ 동 안 배양하면서 세포를 완전히 부착시키고, 이너뷰티필름을 농도 에 따라 PBS에 용해하여 $24 \mathrm{~h}$ 동안 처리 하였다. Well당 $20 \mu \mathrm{L}$ 의 3-(4,5-dimethylthiazol-2-yl)-2,5-diphenyltetrazolium bromide (MTT; Sigma-Aldrich) 용액 $(1 \mathrm{mg} / \mathrm{mL})$ 을 첨가하여 $4 \mathrm{~h}$ 동 안 반응시켰다. MTT 시약의 첨가로 생긴 formazan을 녹이기 위해 서 dimethyl sulfoxide (DMSO; Sigma-Aldrich)를 $100 \mu \mathrm{L}$ 씩 첨가 하고, $1 \mathrm{~h}$ 후 microplate reader (Epoch, BioTek, USA)를 이용하여 $517 \mathrm{~nm}$ 에서 흡광도를 측정하였으며, control (medium only)의 흡광 도 값을 기준으로 세포독성을 비교하였다.

\section{Elastase 억제 활성 측정}

제조된 필름의 주름개선 효과를 평가하기 위해 elastase 활성 억 제능을 확인하였다. 양성대조군은 adenosine을 사용하였으며 0.1 M Tris-HCl buffer (pH 8.0)에 희석한 시료 $220 \mu \mathrm{L}$ 에 $2 \mathrm{mg} / \mathrm{mL}$ $\mathrm{N}$-succinyl-Ala-Ala-Ala-p-nitroanilide $20 \mu \mathrm{L}$ 를 첨가하여 $25^{\circ} \mathrm{C}$ 조건에서 $20 \mathrm{~min}$ 반응시킨 다음, 얼음 위에서 반응을 종결시킨 후 microplate reader (Epoch, BioTek)를 이용하여 $405 \mathrm{~nm}$ 에서 흡광도 를 측정하였다(Moon et al., 2010). 


\section{DPPH 라디칼 소거 활성}

필름으로 제조된 제품의 항산화 효과를 평가하기 위하여 1,1-diphenyl-2-picryl hydrazyl (DPPH)의 자유 라디칼 소거능을 확인하였다. 메탄올에 용해한 $200 \mu \mathrm{M} \mathrm{DPPH} 200 \mu \mathrm{L}$ 에 희석한 시료 를 $50 \mu \mathrm{L}$ 첨가하여 $37^{\circ} \mathrm{C}$ 에서 $30 \mathrm{~min}$ 동안 반응시킨 후, microplate reader (Epoch, BioTek)를 이용하여 $405 \mathrm{~nm}$ 에서 흡광도를 측정하 였다. Ascorbic acid를 양성대조군으로 사용하였으며 천연물 추출 복합물 처리군와 무처리군의 흡광도 감소율로 나타내었다(BrandWilliams et al., 1995).

\section{Tyrosinase 억제 효과 측정}

필름으로 제조된 제품의 미백 효과를 평가하기 위하여 tyrosinase 활성 억제능을 측정하였다. $0.1 \mathrm{M}$ phosphate buffer (pH 6.5) $50 \mu \mathrm{L}$ 에 시료 $50 \mu \mathrm{L}$ 와 $0.1 \mathrm{unit} / \mu \mathrm{L}$ tyrosinase $50 \mu \mathrm{L}$ 를 첨가하여 상온에서 $5 \mathrm{~min}$ 간 반응시켰다. $1 \mathrm{mM} \mathrm{L}-\mathrm{DOPA} 100 \mu \mathrm{L}$ 를 첨가 하여 $37^{\circ} \mathrm{C}$ 에서 $30 \mathrm{~min}$ 간 반응시킨 후 microplate reader (Epoch, BioTek)를 이용하 여 $475 \mathrm{~nm}$ 에서 흡광도를 측정하였다. Arbutin을 양성대조군으로 사 용하였으며 tyrosinase 저해활성은 천연물 추출 복합물 처리군와 무 처리군의 흡광도 감소율로 나타내었다(Sripathi et al., 2016).

\section{Type-1 procollagen C-peptied 합성능 측정}

천연추출복합물과 저분자콜라겐을 함유한 이너뷰티필름의 세 포 내 콜라겐 생성에 미치는 영향을 알아보기 위해 human dermal fibroblast cell (HDF) 세포를 10\% FBS가 들어간 DMEM 세포배양 액에 $37^{\circ} \mathrm{C} 5 \% \mathrm{CO}_{2}$ 조건에서 배양한 후 well당 $1 \times 10^{4} \mathrm{cell}$ 이 되도록 96-well plate에 깔아준 후, $12 \mathrm{~h}$ 동안 배양하면서 세포를 완전히 부 착시켰다. 각 well의 세포들을 무혈청 $\mathrm{DMEM}$ 배양액으로 세척한 다 음 각 well에 시료를 최종 농도 $62.5,125,250,500,1,000,2,000$ $\mu \mathrm{g} / \mathrm{mL}$ 가 되도록 처리한 후 $48 \mathrm{~h}$ 동안 배양하였다. 배양액을 수집 하여 procollagen type $1 \mathrm{C}$-peptide assay kit (Takara Bio Inc., Japan)를 사용하여 콜라겐 함량을 측정하였으며, 이때 콜라겐의 농도 는 kit에 포함되어 있는 표준 용액(Procollagen Type I)으로부터 산출 된 표준곡선으로부터 계산되었다(Ryu et al., 2019).

\section{9. 색도 및 물성 측정}

색도는 필름 시료 2 장을 색도 측정 용기에 빈틈이 없도록 채워 넣은 후, 색차계(Chroma Meter, CR-400; Konica Minolta Inc., Japan)를 사용하여 L (명도), a (+적색도/-녹색도), b (황색도)값을 측정하였다. 이때 대조군으로 유통 중인 제품(S제약. Korea)을 사용 하여 비교하였으며 표준색판의 L값은 92.74 , a값은 0.19 , b값은 3.67 이었으며, 25 회 반복 측정한 후 그 평균값으로 나타내었다. 물성 측 정은 Texture analyzer (ZwickiLine Z0.5 TS; Zwick Roell, Korea)에 screw grips type 8033을 장착하여 test force $0.1 \mathrm{~N}$, test speed 10 $\mathrm{mm} / \mathrm{min}$ 의 조건으로 각각 다른 배치들을 적용하여 측정하였다.

\section{0. 필름의 붕해도 측정}

제조된 필름의 입안 용해시간을 측정하기 위해 붕해시험액 제 2 액을 만들어 시험하였다. 시험액 제조는 $0.2 \mathrm{~N}$ 인산이수소칼륨 $\left(\mathrm{KH}_{2} \mathrm{PO}_{4}\right)$ 시액에 $0.2 \mathrm{~N}$ 수산화나트륨 $(\mathrm{NaOH})$ 시액 $118 \mathrm{~mL}$ 및 물을 넣어 $1 \mathrm{~L}$ 로 맞추고 $\mathrm{pH}$ 6.8임을 확인하였다. 이후 식품공전의 붕해시 험법을 따라 붕해도 시험기(KDIT-200; KUKJEENG, Korea)를 이 용하여 시험을 진행하고 시간을 측정 하였다. 시험군과 대조군(S제 약, Korea)은 각 7개씩 진행되었으며 최종 평균 용해시간으로 나타 내었다.

\section{1. 필름의 안정성 실험}

제조된 제품의 온도 및 광안정성을 시험하기 위해 $50 \pm 2{ }^{\circ} \mathrm{C}$ 조건 에 보관하여 인공광 $\left(120\right.$ 만 $\left.\mathrm{Lux} / \mathrm{hr}, 500 \mathrm{watt} \mathrm{hrs} / \mathrm{m}^{2}\right)$ 을 노출 시켜 경시적 변화에 따른 변색 등의 상태변화를 $0,3,6$ 개월 동안 관찰하 였다.

\section{2. 인체적용시험 피시험자 모집}

본 실험의 피시험자는 총 50 명이며 구글 서베이에서 " 20 대와 30 대 여성을 대상으로 하는 이너뷰티필름의 효능 및 품질 평가" 페이지 를 개설하고 각자의 기본적인 신상정보(성별, 나이, 연락처, 참여가 능성 등)를 묻고 어떠한 식품에서도 알레르기가 없으며, 선천성 질환 이나 만성질환이 없고, 임신부, 수유부가 아니며 병적 증상이나 소견 이 없는 사람들을 선정하였다. 이 연구는 순천대학교 생명윤리위원 회(1040173-201906-HR-019-02)의 검토와 승인을 받아 진행되 었고 총 3 회 방문(사용 전, 사용 후 5 일, 사용 후 10 일)하여 개선 정도 를 측정하였다. 측정 전 동일한 세정제로 세정 및 세안 후 지정된 항 온·항습실(온도: $22 \pm 2^{\circ} \mathrm{C}$, 습도: $50 \pm 5 \%$ )에서 $30 \mathrm{~min}$ 간 안정을 취 한 뒤 측정하였다. 섭취량은 1 일 2 장씩, 총 10 일 분량인 20 장을 제공 하고 피시험자가 가정에서 직접 구강 내 양쪽 볼에 부착할 수 있도록 충분한 설명 후 진행되었다.

\section{3. 피부 개선 정도 평가}

피시험자의 주름 개선 정도를 평가하기 위하여 WillCam (K.L Global, Korea)을 활용하여 측정하였다. WillCam은 접안카메라에 접촉된 피부 표면의 주름을 사진으로 촬영하고 주름정도, 색소잡티, 모공의 정도를 수치로 나타내어 값을 산출하고 산출 값이 높을수록 주름, 색소잡티, 모공이 많은 것으로 측정된다. 동일한 시험담당자가 모든 피시험자의 오른쪽 눈 주변 동일한 곳을 측정하였으며, 산출값 은 시료 사용전과 비교하여 값이 줄어들수록 주름의 개선, 색소잡티 개선, 모공 개선의 효과를 나타낸다. 기기측정은 시료 사용 전( 0 일), 사용 후 5 일, 10 일의 시점에서 수행되었다.

\section{4. 피부치밀도 개선 정도 평가}

피부치밀도 개선 정도 평가를 위하여 고해상도의 초음파를 영 
A

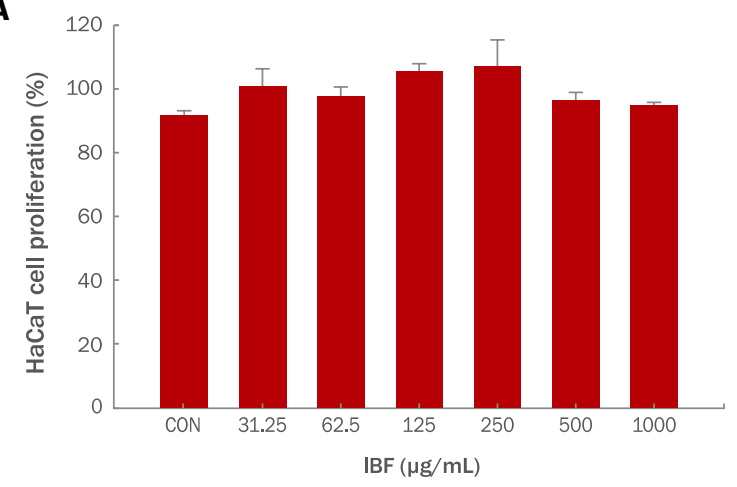

B

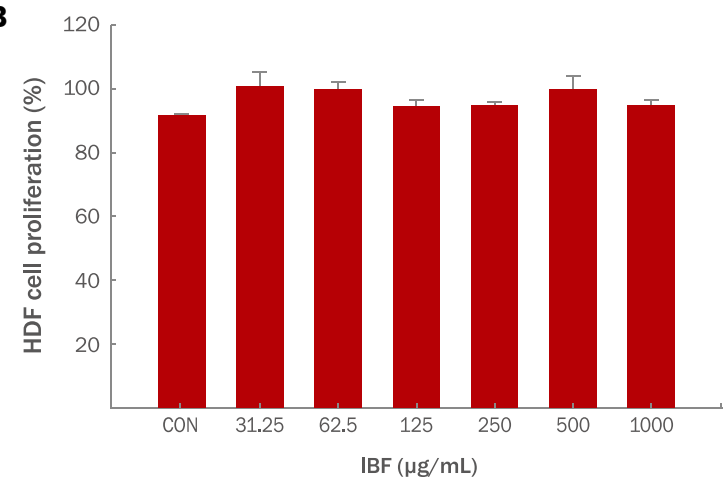

Figure 1. Cell viability determination of HaCaT and HDF treated with IBF through MTT assay.

$\mathrm{HaCaT}(\mathrm{A})$ and HDF (B) were treated with IBF $(31.25,62.5,125,250,500$, and $1000 \mu \mathrm{g} / \mathrm{mL})$ for $24 \mathrm{~h}$ at $37^{\circ} \mathrm{C}$. MTT assay was conducted to evaluate cytotoxicity. Each value is the mean \pm SD of three independent experiments that are significantly different $(p<0.05)$ from the control. IBF, inner beauty film; MTT, 3-(4,5-dimethylthiazol-2-yl)-2,5-diphenyltetrazolium bromide.

상화하는 장치인 USB Ultrasound Scanner (DermaLab USB Ultrasound; Cortex Technology, Denmark)를 활용하였다. 시험 부위에 초음파 검사용 젤을 바르고 Scanner의 probe를 피부와 직 각이 되도록 한 후 동일한 시험담당자가 모든 피시험자의 왼쪽 눈꼬 리 대각선 $3 \mathrm{~cm}$ 부위를 동일한 압력을 가하여 피부치밀도를 측정하 였다. 분석범위는 진피층인 표피 바로 아래에서 피하지방층 윗부분 으로 한정하였으며, 피부치밀도를 의미하는 파라미터인 intensity 를 측정 및 분석하였다. 측정단위는 density이며, 시료 사용 전과 비 교하여 측정값이 증가할수록 피부치밀도가 개선되었음을 의미한다. 기기측정은 시료 사용 전( 0 일), 사용 후 5 일, 10 일의 시점에서 이루 어졌다.

\section{5. 통계처리}

색도, texture, 소비자 설문 조사 결과는 SPSS 프로그램(SPSS 25.0 for windows, SPSS Inc., USA)을 사용하여 기술통계, 빈도분 석, 독립표본 $t$-검정, $\mathrm{K}$-평균군집분석 및 교차분석을 실시하였다. 모든 시험데이터의 통계처리는 SPSS 17.0 for Windows 프로그램 을 이용하여 분석하였다. 피시험자의 피부 개선도에 대한 기기측정 산출값의 변화 여부를 분석하기 위하여 평균, 표준편차, 백분율을 산출하였고, 통계적인 유의성은 paired $t$-test로 분석하였다. 이 때 유의성 차이는 $p<0.05$ 로 설정하였다.

\section{Results and Discussion}

\section{1. 천연추출복합물을 이용한 필름제형 제조}

이너뷰티필름의 필름제형은 저분자 콜라겐을 함유한 한국프라 임제약(주)의 특허기술을 가지고 천연추출복합물을 첨가하여 만들 어 졌으며 크기는 $30 \mathrm{~mm} \times 20 \mathrm{~mm} \times 0.27 \mathrm{~mm}$ (가로 $\times$ 세로 $\times$ 두
께)로 제작되었다. 실험에 첨가된 필름은 콜라겐과 제형 성분은 고 정 되었고 천연추출복합물의 농도만 $2000,1000,500,250,125$, $62.5,31.25 \mu \mathrm{g} / \mathrm{mL}$ 으로 조정되었으며 최종 수분함량은 $10 \pm 2 \%$ 로 건조되었다. 건조되어 진공포장 된 샘플은 실험 전 세포 배지 및 phosphate-buffered saline (PBS; Welgene, Korea)에 녹여서 사용 되었다.

\section{2. 이너뷰티필름의 피부 세포 독성 평가}

이너뷰티필름의 필름 제형은 모두 식품 소재로써 천연추출복합물 과의 혼합에 의한 세포독성을 평가하기 위하여 $\mathrm{HaCaT}$ 세포와 $\mathrm{HDF}$ 세포를 각각 농도 별로 처리하여 $24 \mathrm{~h}$ 배양한 후 MTT assay를 수행 하였다(Figure 1A, B). 각각의 세포에서 PBS만 첨가한 음성대조군 $(\mathrm{CON})$ 을 사용하여 세포생존율을 비교 하였을 때 이너뷰티필름을 처 리한 $32.25 \mu \mathrm{g} / \mathrm{mL}$ 부터 $1000 \mu \mathrm{g} / \mathrm{mL}$ 농도까지의 세포생존율에 유의 미한 세포사멸의 변화는 없는 것으로 확인되어 이너뷰티필름에 대한 피부세포의 독성은 없는 것으로 판단된다. 이와 같은 결과는 선행연 구의 천연추출복합물에서도 독성이 없음을 확인한 결과와 식품원료 로 만들어진 제형이 세포독성이 없는 것을 재확인 할 수 있는 결과로 사료된다.

\section{Elastase 억제 활성 측정}

Elastase 억제능은 피부노화의 척도로 사용되며 노화와 외부자 극에 따라 elastase의 활성이 높아지는 것으로 알려져 있다(Baud et al., 2013). 본 연구에서 elastase억제 활성을 알아보기 위해 이너뷰 티필름과 음성대조군의 흡광도 감소율로 나타내었다. 양성대조군은 adenosine $2000 \mu \mathrm{g} / \mathrm{mL}$ 을 사용했으며 이너뷰티필름은 $62.5 \mu \mathrm{g} / \mathrm{mL}$ 부터 $2000 \mu \mathrm{g} / \mathrm{mL}$ 농도까지 처리 하였으며 $125 \mu \mathrm{g} / \mathrm{mL}$ 에서부터 유의 적인 elastase 억제 효과가 있는 것으로 확인 되었다(Figure 2A). 이 너뷰티필름 처리 농도 $62.5 \mu \mathrm{g} / \mathrm{mL}$ 에서는 약 $3.5 \%$ 의 억제 효능 나타 
A
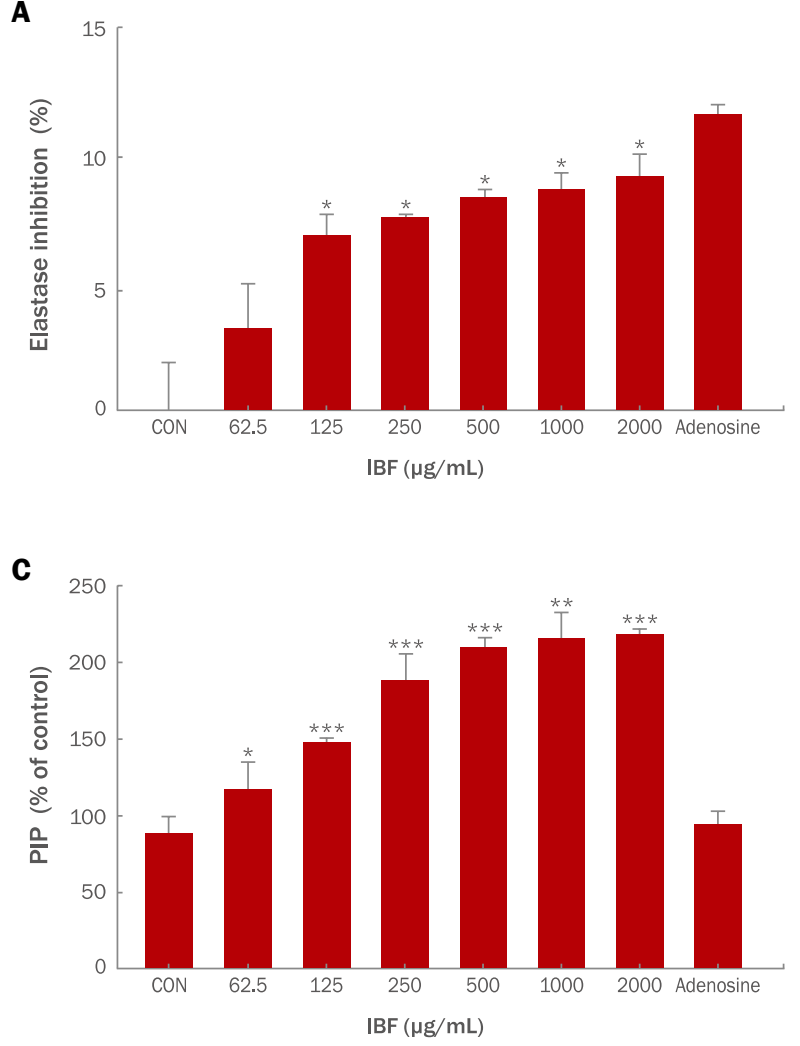

냈지만 유의적인 수치는 아니였다. 이너뷰티필름 $125 \mu \mathrm{g} / \mathrm{mL}$ 농도에 서부터 $7.2 \%$ 의 억제효능을 나타냈으며 $2000 \mu \mathrm{gg} / \mathrm{mL}$ 에선 $9.7 \%$ 의 유 의적인 elastase 억제 효능을 나타내었다. 양성대조군인 adenosine은 약 $12.9 \%$ 의 억제효능을 보였으며 동일 농도 대비 이너뷰티필름과 약 $3.2 \%$ 의 차이를 보였다. 따라서 이너뷰티필름이 주름개선에 유의한 효과가 있다고 판단 된다.

\section{Collagenase 억제 활성 측정}

Collagenase 는 elastase와 같이 피부노화나 외부 자극에 따라 활 성이 높아져 피부 주름 생성에 많은 영향을 주는것으로 알려져 있다 (Kim et al., 2011). 피부 주름억제에 collagenase 억제능에 따라 주 름을 개선 할수 있다고 알려져 있다. 이너뷰티필름의 collagenase의 효능을 알아보기 위해 음성대조군은 PBS만 처리한 처리군으로 사용 되었고 이너뷰티필름은 $32.25 \mu \mathrm{g} / \mathrm{mL}$ 부터 $500 \mu \mathrm{g} / \mathrm{mL}$ 까지 처리되 었으며 고시형 양성대조군인 adenosine $(500 \mu \mathrm{g} / \mathrm{mL}$ )과 비교 하였 다. 이너뷰티필름 $32.25 \mu \mathrm{g} / \mathrm{mL}$ 에서 약 $16.3 \%$ 의 억제효능을 나타냈 으며 $125 \mu \mathrm{g} / \mathrm{mL}$ 부터 $500 \mu \mathrm{g} / \mathrm{mL}$ 까지는 $20 \%$ 이상의 억제능을 나 타냈다(Figure $2 \mathrm{~B}$ ). 동일농도인 $500 \mu \mathrm{g} / \mathrm{mL}$ 의 양성대조군은 $35 \%$ 의 억제율을 나타내 동일농도 대비 약 $15 \%$ 의 차이를 보였으나 32.25 $\mu \mathrm{g} / \mathrm{mL}$ 부터 유의적인 억제 효율을 보이는 것에서 이너뷰티필름이 collagenase 억제를 통한 주름개선에 효과가 있다고 판단된다.

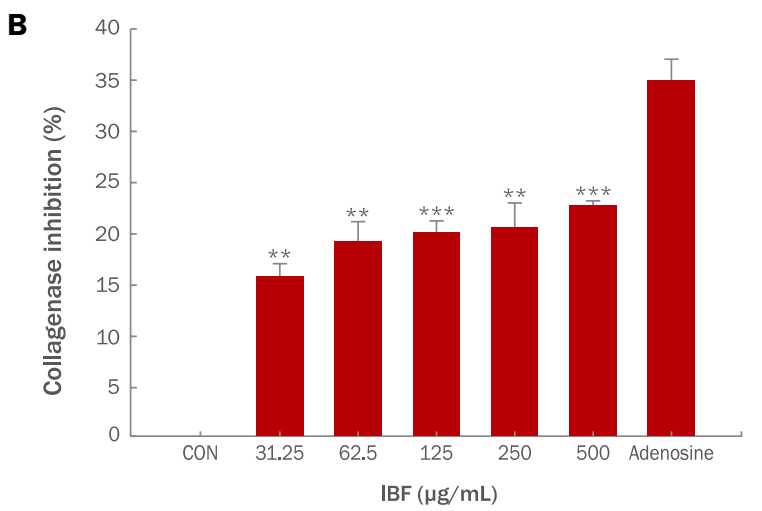

Figure 2. The effects of IBF on collagen-related digestion enzymes and pro-collagen synthesis.

Comparison of the elastase inhibition effect of IBF through enzymatic experiment (A). The positive control was adenosine $(2000 \mu \mathrm{g} / \mathrm{mL}$ ). Collagenase inhibition ability of IBF (B). Expression levels of pro-collagen type I in HDF cells that were treated for $48 \mathrm{~h}$ with the indicated IBF concentrations and measured using ELISA assay (C). Values are presented as mean $\pm \mathrm{SD}$ of the percentage of control optical density (experiments were performed in triplicates). Asterisks indicate significant differences of triplicate data $\left({ }^{*} p<\right.$ $0.05 ;{ }^{* *} p<0.01,{ }^{* * *} p<0.001$ ) between negative control and IBFtreated group using Student's $t$-test. IBF, inner beauty film; SD, standard deviation.

\section{Type-1 procollagen C-peptied 합성능 측정}

저분자 콜라겐 펩타이드 및 천연추출복합물을 포함하는 필름소재 의 주름개선 효과를 평가하기 위해 Type-1 pro-collagen 합성 촉 진 활성을 확인하였다. Pro-collagen은 collagen 구조의 아미노 말 단과 카르복시 말단에 propeptide라는 염기서열을 가지고 있으며, propeptide는 pro-collagen의 접힘(folding)을 도와주고 collagen 분자로부터 분리된다고 알려져 있다. 이때 분리된 propeptide의 양 을 측정함으로써, 세포 내에서의 collagen 생합성양을 확인할수 있 다(Talwar et al., 1995). 양성대조군은 adenosine $(2,000 \mu \mathrm{g} / \mathrm{mL})$ 을 사용하였으며 음성대조군은 $\mathrm{PBS}$ 만을 사용하여 비교하였다. 이너 뷰티필름은 $62.5 \mu \mathrm{g} / \mathrm{mL}$ 에서는 음성대조군(100\%) 대비 $134.4 \%$ 의 procollagen 분비능를 나타내었으며 $2,000 \mu \mathrm{gg} / \mathrm{mL}$ 에서는 $202 \%$ 의 콜 라겐 분비능을 나타내었다(Figure $2 \mathrm{C}$ ). 최근 타 선행연구에서 저분자 콜라겐의 섭취에 의한 collagen의 합성 촉진에 대한 연구들이 많이 보고 되어 있다(Jeong et al, . 2008; Zhang et al., 2020). 하지만 본 연구에서 사용된 저분자 콜라겐의 양은 모든 시험 농도에서 동일양 이 함유 되었고 천연추출복합물의 농도가 증가됨에 따라 procollagen 의 농도가 증가 되는 것으로 나타났다. 결과적으로 저분자 콜라겐의 영향보다 천연추출복합물의 기능성으로 판단된다. 이와 같은 결과로 천연추출복합물에 의한 procollagen의 분비능의 증가로 판단된다.

\section{DPPH 자유 라디칼 소거능 측정}


A

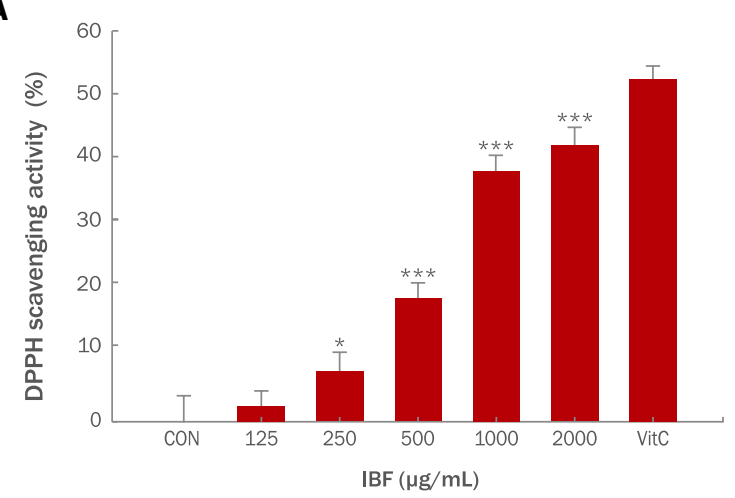

B

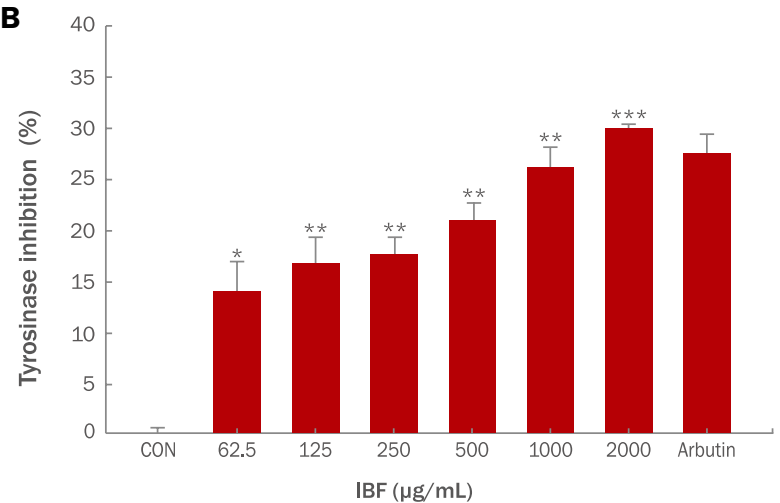

Figure 3. Antioxidant and whitening effects of IBF.

DPPH radical scavenging activity of IBF (A). Comparison of DPPH scavenging activity effect of IBF with different treatment concentrations. The positive control was Vitamin C (2000 $\mu \mathrm{g} / \mathrm{mL})$. (B) Tyrosinase inhibitory activities of IBF. Arbutin was the positive control $(2000 \mu \mathrm{g} / \mathrm{mL})$. Values are mean $\pm \mathrm{SD}$ of three experiments. Asterisks indicate significant differences $\left({ }^{*} p<0.05 ;{ }^{* *} p<0.01\right.$, $\left.{ }^{* * *} p<0.001\right)$ between negative control and the IBF-group using Student's $t$-test. DPPH, 2,2-diphenyl-1-picrylhydrazyl; Vit. C, Vitamin C; IBF, inner beauty film; SD, standard deviation.

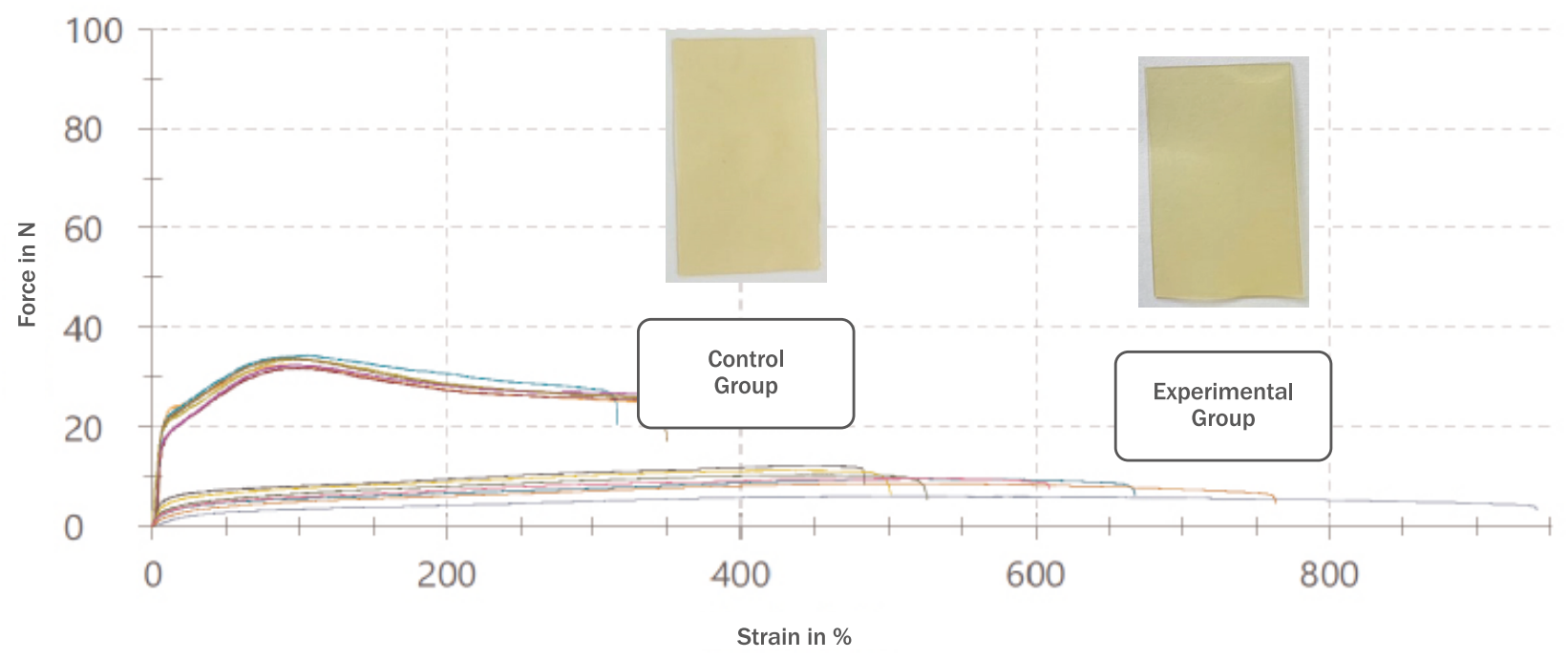

Figure 4. Stress strain curves of inner beauty film.

The result of tension tests obtained using 25 samples. Texture analyzer measured with screw grip type 8033 at test force $0.1 \mathrm{~N}$ and test speed $10 \mathrm{~mm} / \mathrm{min}$.

자유 라디칼 소거 활성은 피부 노화를 억제시키는 역할을 하며 이 작용은 질병과 노화를 억제하는데 중요한 역할을 하는 것을 알려져 있다(Assimopoulou et al., 2005). 이너뷰티필름의 항산화 활성을 알아보기 위해 $125 \mu \mathrm{g} / \mathrm{mL}$ 부터 $2000 \mu \mathrm{g} / \mathrm{mL}$ 까지 항산화 활성을 확 인 하였다(Figure 3A). 음성대조군은 PBS을 사용하였고 양성대조군 은 vitamin $\mathrm{C}$ 를 이용하여 소거능을 확인하였다. 처리군 $125 \mu \mathrm{g} / \mathrm{mL}$ 농도에서 $1.17 \%$ 의 소거율을 보였으나 유의적인 수치는 아니 였다. 하지만 $250 \mu \mathrm{g} / \mathrm{mL}$ 부터 $8.5 \%, 500 \mu \mathrm{g} / \mathrm{mL}$ 에서 $19 \%$, 양성대조군과 동일 농도인 $2000 \mu \mathrm{g} / \mathrm{mL}$ 에서 $40.1 \%$ 의 유의미한 자유라디칼 소거 능이 확인되었다. 양성대조군은 $50 \%$ 의 소거능을 보여 이너뷰티필름
과 약 $10 \%$ 의 차이를 보였지만 유의성이 높은 결과로 보아 항산화 효 과가 탁월한 것으로 판단된다.

\section{Tyrosinase 활성 억제능 측정}

Tyrosinsase는 미백의 지표 마커로서 세포내 멜라닌 생성을 촉진하는 것으로 알려져 있고 억제할 경우 멜라닌의 생성이 억 제되어 미백의 활성이 나타나는 것으로 알려져 있다(Hearing, 2011). Tyrosinase 저해 활성능은 L-tyrosine이 기질로 작용하 여 tyrosinase에 의해 L-tyrosine이 L-DOPA로, L-DOPA가 다시 L-DOPA quinone으로 전환되는 원리를 이용하였다(Hwang et al., 
1997). 음성대조군인 $\mathrm{PBS}$ 와 비교해서 $62.5 \mu \mathrm{g} / \mathrm{mL}$ 에서 $14.3 \%$ 의 억제 효능을 나타내었다. $2000 \mu \mathrm{g} / \mathrm{mL}$ 에서는 $30.6 \%$ 의 억제효율을 보여 양성대조군인 arbutin의 $27.7 \%$ 보다 높은 효과를 나타내었다 (Figure 3B). 동일 농도 $2,000 \mu \mathrm{g} / \mathrm{mL}$ 에서 양성대조군보다 미백활 성이 $2.3 \%$ 높게 나타나 이너뷰티필름이 미백에 유의미한 효과가 있 는 것으로 사료된다.

\section{8. 색도 및 물성 측정}

색도는 객관적인 명도값을 나타냄으로써 품질을 판단하고 섭취함 에 있어 심미적인 요소를 고려하기 위해 수치값으로 나타내는 실험 방법이다(Lim et al., 2010). 시험군의 명도(L)값은 24.42 , 대조군의 명도값은 28.62로 대조군 시료의 색도가 유의적으로 높게 나타났다. 적색도(a)값은 실험군이 0.17 , 대조군이 0.47 로 실험군이 유의적으 로 낮은 값을 나타내었고, 황색도(b) 측정 결과, 실험군이 3.02 , 대조 군이 4.22로 실험군이 유의적으로 낮은 값을 나타내었다(Figure 4). 인장강도는 최대 하중 $\left(\mathrm{F}_{\max }\right)$ 값과 파단 시 하중 $\left(\mathrm{F}_{\mathrm{break}}\right)$ 값은 대조군에 비 해 실험군이 유의적으로 낮게 나타났다. 최대 하중 시 늘어난 거리 $\left(\mathrm{dL}\right.$ at $\mathrm{F}_{\max }$ )는 대조군이 약 $96 \%$, 실험군이 약 $478 \%$ 로 실험군이 유 의적으로 높은 값을 나타내었고, 파단 시 늘어난 거리(dL at break) 도 대조군이 약 $373 \%$, 실험군이 약 $592 \%$ 로 실험군이 유의적으로 높 은 값을 나타내었다(Table 1). 일반적으로 인장강도와 신장율은 반비 례 관계이며 인장강도가 증가하면 신장율은 감소하게 된다. 이는 제 품 포장에 고려해야 하는 중요한 요소임으로 실험결과를 바탕으로 포 장 재질 선택에 고려 되어야 한다.

\section{9. 필름의 붕해도 측정}

빠른 붕해도는 구강점막으로 섭취 시 이물감을 감소시기는 중요 한 요소로 이너뷰티필름을 평가하였다. 일반적으로 필름소재는 구 강으로 복용됨으로 산이나 알칼리성 $\mathrm{pH}$ 에서 녹는 것 보다 구강내 $\mathrm{pH}$ 에서 빠르게 녹아 흡수되는 것이 중요하다(Kim et al., 2019). 식 품일반시헙법의 붕해시험 기시법의 제 2 액의 제조로 시행 되었으 며 대조군은 시판중인 콜라겐 $\mathrm{ODF}$ 필름을 사용하였다. 평균 붕해시 간은 대조군은 $245 \mathrm{~s}$ 가 소요되었으며 이너뷰티필름은 $250 \mathrm{~s}$ 가 소요 되었다(Table 2). 대조군으로 사용된 제품은 본 연구에서 사용된 이 너뷰티필름과 성분과 함량, 중량 등이 다르지만 제품의 유형과 사용 방법 등의 기본 개념이 같기 때문에 대조군으로 사용이 가능한 것으 로 판단되었으며 대조군으로 사용된 필름의 붕해시간은 242-250 s 사이 인 것에 반해 이너뷰티필름은 203-300 s 사이의 차이를 보이 는 것은 시작품으로써의 균질화에 문제를 해결해야 할 것으로 사료 된다.

\section{0. 필름의 안정성 실험}

온도와 광안정성을 측정하기 위해 저장 전 이너뷰티필름과 3 개월 6 개월 보관된 제품의 경시적 경시적 변화 및 색의 변색은 나타나지 않았다(Table 3). 이너뷰티필름을 3 개월 $(n=3)$ 과 6 개월 $(n=3)$ 의 보관 후 개봉하여 확인 하였으며 저장에 사용된 이너뷰티필름은 포장, 밀 봉되어 있는 상태로 진행되었으며 외관의 산패, 변색, 변취 등의 변 화를 보이지 않았다. 본 연구에서는 밀봉되지 않은 제품은 1 일 이상 보관 시 최종 수분 량이 급격하게 줄어들어 섭취하기 어려운 상 태로 변형되어 포장 및 밀봉된 상태로 실험을 진행하였다. 밀봉되어

Table 1. Tensile strength and maximum strain test of inner beauty film

\begin{tabular}{lcccc}
\hline & $\mathrm{F}_{\max }(\mathrm{kgf})$ & $\mathrm{dL}$ at $\mathrm{F}_{\max }(\%)$ & $\mathrm{F}_{\text {break }}(\mathrm{kgf})$ & $\mathrm{dL}$ at break $(\%)$ \\
Control group & $3.38 \pm 0.10$ & $96.87 \pm 6.91$ & $2.24 \pm 0.28$ & $373.45 \pm 37.45$ \\
Experimental group & $1.04 \pm 0.13$ & $478.32 \pm 46.73$ & $0.65 \pm 0.14$ & $592.15 \pm 109.12$ \\
$t$-value $(p)$ & $35.361(0.000)^{* * *}$ & $19.780(0.000)^{* * *}$ & $-12.330(0.000)^{* * *}$ & $4.643(0.003)^{* *}$ \\
\hline${ }^{* *} p<0.01 ;{ }^{* * *} p<0.001$. & & &
\end{tabular}

Table 2. Results of disintegration test of inner beauty film

\begin{tabular}{|c|c|c|}
\hline \multirow{2}{*}{ Sample } & \multicolumn{2}{|c|}{ Disintegration time (s) } \\
\hline & Control group & Experimental group \\
\hline 1 & 243 & 224 \\
\hline 2 & 250 & 212 \\
\hline 3 & 242 & 280 \\
\hline 4 & 250 & 300 \\
\hline 5 & 242 & 203 \\
\hline 6 & 244 & 230 \\
\hline 7 & 244 & 250 \\
\hline Mean & 245 & 250 \\
\hline
\end{tabular}

${ }^{\dagger}$ Each sample is shown with independent experimental results. 
있는 상태에서의 온도에 의한 안정성은 검증되었지만 밀봉되지 않 은 상태에서의 안정성은 추후 연구를 진행해야 할 것으로 사료된다.

\section{1. 인체적용시험 피부 개선 평가}

\section{1) 주름개선}

시료 사용 전( 0 일), 사용 후 5 일, 10 일 각각의 주름개선 평가는 오 른쪽 눈가 주름의 정도로 평가되었고, 사용 전(0일; 4.94) 대비 사용 후 5일, 10 일 각각 $4.02(p<0.05), 3.14$ ( $p<0.001)$ 의 산출 값으로 유의적으로 주름이 감소하는 것으로 나타났으며, 각각 $10.9 \%$ (사용 후 5일) 및 $32.1 \%$ (사용 후 10일)의 주름 개선율을 나타났다(Table 4). 이와 같은 결과는 in vitro에서 피부세포에서의 콜라겐 생성 촉 진과 collagenase활성 억제로 인한 주름개선의 효과로 사료된다. 타 연구에서도 콜라겐의 섭취가 피부에 도움을 줄 수 있는 것으로 보고 되어 있고 본 실험에서도 저분자 콜라겐 섭취 효과와 천연추출복합 물의 collagenase활성 억제로 유의미한 효과를 나타낸 것으로 사료 된다(Kim et al., 2019).

\section{2) 피부 색소 잡티 개선}

시료 사용 전( 0 일)과 사용 후 5 일, 10 일 각각의 피부 색소·잡티 개 선 평가는 오른쪽 눈가 부분의 기기측정 산출 결과를 반영하였고, 사용 전(0일; 3.22) 대비 사용 후 5일, 10 일 각각 2.71 ( $p<0.001)$, 2.16 ( $p<0.001)$ 로 유의적으로 감소하는 것으로 나타났으며, 각각 사 용 전 대비 $10.36 \%$ (사용 후 5일) 및 $32.53 \%$ (사용 후 10 일)의 피 부 색소·잡티 개선율을 확인하였다(Table 4). 이는 tyrosinase의 억 제활성에 대한 효과로 사료되며 선행연구에서의 억제활성이 높았던 만큼 이너뷰티필름에 함유된 천연추출복합물에 의한 효과로 사료된 다(Kim et al., 2019).
3) 피부 모공 수축

모공의 변화는 과도한 피지생성으로 모공이 막히거나 염증성 만 성질환에 의한 것으로 스트레스, 유전, 호르몬의 불균형, 세균감염 과 같은 다양한 요인에 의해 발생하고 이로 인한 모공의 팽창 혹은 피지가 쌓이는 현상이 많이 발생 한다(Shin \& Seo, 2019). 이너뷰티 필름의 모공에 미치는 영향을 알아보기 위해 WillCam에 부착된 마 이크로 스코프를 이용한 피부 모공 수축 정도 평가는 눈가 동일 부 분을 측정한 결과로, 시료 사용 전( $(0$ 일; 2.46)과 사용 후 5 일, 10 일 각각 1.68 ( $p<0.001), 1.2$ ( $p<0.001)$ 로 유의적으로 감소하는 것으 로 나타났으며, 각각 사용 전 대비 $17.34 \%$ (5일 사용 후) 및 $31.54 \%$ (10일 사용 후)의 피부 모공 개선율을 확인하였다(Table 4). 이와 같 은 결과는 주름개선과 항염증 효과로 설명될 것으로 판단 되나 추가 적인 모공수축과 관련한 바이오마커에 대한 연구를 진행해야 할 것 으로 사료된다.

4) 피부치밀도 개선

피부치밀도는 피부주름과 밀접한 관계가 있으며 치밀도가 높아 짐에 따라 주름개선 효과도 나타나는 것으로 알려져 있다(Han et al., 2016). 시료의 피부치밀도 개선 효과는 피시험자 왼쪽 눈가 대 각선 $3 \mathrm{~cm}$ 부근의 동일 부분을 동일한 압력을 가하여 측정한 결 과, 시료 사용 전(0일; 38.18$)$ 과 사용 후 5 일 및 10 일은 각각 40.87 ( $p<0.001), 42.5$ ( $p<0.001)$ 로 유의적으로 증가하는 것으로 나타났 으며, 각각 사용 전 대비 $8.61 \%$ (사용 후 5 일) 및 $12.77 \%$ (사용 후 10 일)의 피부치밀도 개선율을 확인하였다(Table 4). 이너뷰티필름 의 저분자 콜라겐의 흡수와 천연추출복합물의 콜라겐 생성 촉진 및 collagenase, elastase의 억제를 통한 피부치밀도 개선에 의한 복합 적 주름개선의 효과로 사료된다.

Table 3. Stability results of artificial sun lamp test of inner beauty film on storage time

\begin{tabular}{lccc}
\hline & & Storage time (month) & \\
\cline { 2 - 3 } Sample $^{*}$ & 0 & 3 & 6 \\
1 & Stable & Stable & Stable \\
3 & Stable & Stable & Stable \\
\hline
\end{tabular}

*1,200,000 Lux/hr, 500 watt hrs/m².

Table 4. Results of human clinical study

\begin{tabular}{|c|c|c|c|}
\hline \multirow{2}{*}{ Function } & \multicolumn{3}{|c|}{ Mean score (\% of 0 day) } \\
\hline & 0 day & 5 days & 10 days \\
\hline Wrinkle improvement & $4.94 \pm 2.09(0)$ & $4.02 \pm 1.87(10.92)^{* \dagger}$ & $3.14 \pm 1.91(32.18)^{* * *}$ \\
\hline Skin melanin \& brown spot improvement & $3.22 \pm 1.77(0)$ & $2.71 \pm 1.82(10.36)^{* * *}$ & $2.16 \pm 2.01(32.53)^{* * *}$ \\
\hline Skin pore improvement & $2.46 \pm 1.71(0)$ & $1.68 \pm 1.69(17.34)^{* * *}$ & $1.20 \pm 1.44(31.54)^{* * *}$ \\
\hline Skin density improvement & $38.18 \pm 9.42(0)$ & $40.87 \pm 8.77(8.61)^{* * *}$ & $42.50 \pm 9.43(12.77)^{* * *}$ \\
\hline
\end{tabular}

${ }^{\dagger}$ Means \pm S.D. $(\mathrm{n}=50) ;{ }^{*} p<0.05 ;{ }^{* *} p<0.01 ;{ }^{* * *} p<0.001$. 


\section{Conclusion}

본 연구는 저분자 콜라겐이 함유된 제형에 천연추출복합물과 의 혼합을 통하여 향장기능성을 향상시킨 구강부착형 이너뷰티필 름을 개발하여 피부개선의 기능성과 안정성 및 인체적용시험을 통 한 검증을 진행하였다. 천연추출복합물은 선행연구로 향장기능성 소재로의 가능성을 확인하였고 이를 바탕으로 제형을 만들어 피부 개선 효과를 확인하였다. 제형에 사용된 원료는 식품원료로 등록 된 것을 구매하여 사용되었고 함유된 천연추출복합물도 선행연구에 서 세포독성이 없는 것으로 확인되었으나 제형과의 혼합에 대한 독 성 확인이 필요했다. 피부세포인 $\mathrm{HaCaT}$ 세포와 $\mathrm{HDF}$ 세포를 통하여 독성평가를 실시했을 때 $1000 \mu \mathrm{g} / \mathrm{mL}$ 까지도 유의미적인 세포독성 의 수치는 확인되지 않았다. 또한 피부 노화에 따른 주름의 원인인 collagenase와 elastase은 $125 \mu \mathrm{g} / \mathrm{mL}$ 일 때 $20.8 \%, 12.5 \%$ 로의 유 의미적인 억제 효과를 나타낸 것을 확인하였다. 선행연구에서 확인 한 천연추출복합물의 효능도 높은 수준의 억제 효과를 확인하였고 본 실험에도 같은 결과를 확인하였다. 이너뷰티필름이 procollagen 의 생성에도 효과가 있는 것으로 확인되었다. 최근 콜라겐의 흡수를 통하여 procollagen의 생성을 높일 수 있다는 논문이 보고 되어 본 실험에서도 영향을 미칠수 있다고 생각 되었으나 실험에 사용된 제 형의 용량은 모든 농도에서 같은 용량이 사용되었고 천연추출복합 물의 증가에 따른 procollagen의 발현의 증가가 나타나는 것으로 확 인됨에 따라 천연추출복합물의 효과로 사료된다(Kim et al,. 2015; Lee \& Ryu, 2018).

천연추출복합물이 함유된 이너뷰티필름은 항산화와 미백활성에 도 효과를 나타내었다. 항산화는 $250 \mu \mathrm{g} / \mathrm{mL}$ 에서부터 유의적인 자 유라디칼 소거능을 통한 항산화 효과를 확인할 수 있었으며 미백에 서는 $62.5 \mu \mathrm{g} / \mathrm{mL}$ 에서 부터 유의적인 효과가 있는것으로 확인 되었 다. 미백활성과 관련된 연구에서는 $2000 \mu \mathrm{g} / \mathrm{mL}$ 첨가군에서 양성대 조군보다 $2.9 \%$ 높은 tyrosinase 억제 효과를 확인할 수 있었다. 이 는 선행연구결과와도 같으며 제형 변화에 따른 향장기능성 감소에 영향이 없는 것으로 판단된다.

이너뷰티필름의 물성, 안정성에 대한 연구도 진행한 결과 대조군 으로 사용된 콜라겐 필름은 시판되어 있는 제품으로써 본 연구에서 사용된 이너뷰티필름과 비교했을 때 물성에 대한 강도는 높았으나 변형율은 낮은 특징을 보였다. 하지만 이너뷰티필름은 인장강도는 낮았으나 변형율을 높아 섭취 시 식감에서의 부드러운 효과를 낼 수 있을 것으로 판단되었다. 또한 시작품을 제작한 뒤 6 개월 동안 광안 정성 및 경시적 안정성 결과에서도 안정적인 것으로 확인되었다. 산 패나 변색, 변취 등의 경시적 변화는 나타나지 않으나 밀봉된 상태 의 보관으로 한정적 결과를 확인하였다. 추후 포장이나 밀봉되지 않 은 상태에서의 안정성도 연구되어야 것으로 사료된다.

이너뷰티필름을 사용한 인체적용시험에서 피부개선 효과를 사용 전, 사용 후 5 일 및 10 일 동안 실험이 진행되었으며 피부 주름개선,
색소잡티개선, 모공수축 및 피부치밀도의 개선에서 사용 전 대비 사 용 후 5 일 및 10 일에서 유의적 개선 효과를 나타내었다. 또한, 연령 에 따른 분석 결과에서는 20 대보다 30 대에서 피부주름 개선, 피부 색소·잡티 개선, 피부 모공 개선 및 피부치밀도 개선율이 더 높게 증 가한 것으로 나타났다. 종합하면 이너뷰티필름은 in vitro 시험과 인 체적용시험결과로 판단했을 때 피부 주름, 색소잡티개선, 모공수축 및 피부치밀도의 개선에 도움을 주는 것으로 판단된다. 본 연구에서 사용된 저분자콜라겐과 천연추출복합물의 ODF제형은 기존 피부 흡 수 콜라겐과 먹는 콜라겐의 흡수율 및 효능 비교연구를 후속 연구로 진행이 필요 할 것으로 사료되며 이를 활용한 화장품 산업과 식품산 업에서 응용분야를 넓힐 수 있을 것으로 기대한다.

\section{Author's contribution}

DSK designed all experimental investigations, and developed the process for analyzed data, and wrote the manuscript. JE, JYS, JHP, IJH, and EYN performed natural products extraction and enzymatic experiments. BSL, SYP and GK performed cell experiments. NYS make a check on a final manuscript.

\section{Author details}

Dong-Sub Kim (Research Director), Division of Natural Product Research, Korea Prime Pharmacy CO., LTD., 211, Jungang-ro, Dong-gu, Gwangju (61473), Korea; InJun Han (Deputy General Manager), Division of Natural Product Research, Korea Prime Pharmacy CO., LTD., 211, Jungang-ro, Dong-gu, Gwangju (61473), Korea; Byung Soo Lee (Manager), Division of Natural Product Research, Korea Prime Pharmacy CO., LTD., 211, Jungang-ro, Dong-gu, Gwangju (61473), Korea; Sang-Yun Park (Manager), Division of Natural Product Research, Korea Prime Pharmacy CO., LTD., 211, Jungang-ro, Donggu, Gwangju (61473), Korea; Eun Yeong Nho (Assistant Manager), Division of Natural Product Research, Korea Prime Pharmacy CO., LTD., 211, Jungang-ro, Donggu, Gwangju (61473), Korea; Ji Eom (Assistant Manager), Division of Natural Product Research, Korea Prime Pharmacy CO., LTD., 211, Jungang-ro, Dong-gu, Gwangju (61473), Korea; Ji Young Suh (Staff), Division of Natural Product Research, Korea Prime Pharmacy CO., LTD., 211, Jungang-ro, Dong-gu, Gwangju (61473), Korea; Geon Kim (Staff), Division of Natural Product Research, Korea Prime Pharmacy CO., LTD., 211, Jungang-ro, Dong-gu, Gwangju (61473), Korea; Jihyun Park (Staff), Division of 
Natural Product Research, Korea Prime Pharmacy CO., LTD., 211, Jungang-ro, Dong-gu, Gwangju (61473), Korea; Nak-Yun Sung (General Manager), Division of Natural Product Research, Korea Prime Pharmacy CO., LTD., 211, Jungang-ro, Dong-gu, Gwangju (61473), Korea.

\section{References}

Assimopoulou AN, Sinakos Z, Papageorgiou VP. Radical scavenging activity of Crocus sativus L. extract and its bioactive constituents. Phytotherapy Research, 19: 9971000, 2005.

Baud S, Duca L, Bochicchio B, Brassart B, Belloy N, Pepe A, Dauchez M, Martiny L, Debelle L. Elastin peptides in aging and pathological conditions. Biomolecular Concepts, 4: 65-76, 2013.

Brand-Williams W, Cuvelier ME, Berset C. Use of a free radical method to evaluate antioxidant activity. $L W T$ Food Science and Technology, 28: 25-30, 1995.

Chai HJ, Li JH, Huang HN, Li TL, Khan I, Shiau CY, Wu CJ. Effects of sizes and conformations of fish-scale collagen peptides on facial skin qualities and transdermal penetration efficiency. Journal of Biomedicine and Biotechnology, 2010: 757301, 2010.

Choi YL, Park EJ, Kim E, Na DH, Shin YH. Dermal stability and in vitro skin permeation of collagen pentapeptides (KTTKS and palmitoyl-KTTKS). Biomolecules and Therapeutics, 22: 321-327, 2014.

Han SK, Kim HT, kim YM, Park SM, Lee JN, Oh SH, Ha HY. Improvement of dermal compactness by mixed extracts of three medicinal herbs. Journal of Investigative Cosmetology, 12: 221-225, 2016.

Hearing VJ. Determination of melanin synthetic pathways. Journal of Investigative Dermatology, 131: E8-E11, 2011.

Ichikawa S, Morifuji M, Ohara H, Matsumoto H, Takeuchi $\mathrm{Y}$, Sato K. Hydroxyproline-containing dipeptides and tripeptides quantified at high concentration in human blood after oral administration of gelatin hydrolysate. International Journal of Food Sciences and Nutrition, 61: 52-60, 2010.

Jeong HS, Kwon MC, Han JG, Ha JH, Jin L, Kim JC, Kwak
HG, Hwang BY, Lee HY. Enhancement of skin immune activation effect of collagen peptides isolated from Asterias amurensis. Korean Journal of Food Sciences and Technology, 40: 522-527, 2008.

Jeong HS, Jang HS, Cho YH, Lee GW. The development of dispersing oral disintegrating film for Asparagus cochinchinensis extract using insoluble microparticle. Korean Society for Biotechnology and Bioengineering, 34: 159-166, 2019.

Kang $\mathrm{HH}$. Anti-aging in cosmetics. Journal of the Society of Cosmetic Scientists of Korea, 23: 57-73, 1997.

Kim HW, Kim DS, Sung NY, Han IJ, Lee BS, Park SY, Eom J, Suh JY, Park J, Yu AR, Kim JS. Development of functional cosmetic material using a combination of Hippophae rhamnoides fruit, Rubus fruticosus Leaf and Perillae folium leaf extracts. Asian Journal of Beauty and Cosmetology, 17: 477-488, 2019.

Kim JK, Lee JH, Bae IH, Seo DB, Lee SJ. Beneficial effect of a collagen peptide supplement on the epidermal skin barrier. Korean Journal of Food Science and Technology, 43: 458-463, 2011.

Kim YS, Jung EY, Koh HJ, Hong YH. Effects of formulation containing garlic extract on functional skin care: antioxidation and inhibitive activities of collagenase, elastase and tyrosinase. Asian Journal of Beauty and Cosmetology, 13: 469-476, 2015.

Larrauri JA, Rupérez P, Saura-Calixto F. Effect of drying temperature on the stability of polyphenols and antioxidant activity of red grape pomace peels. Journal of Agricultural and Food Chemistry, 45: 1390-1393, 1997.

Lee JM, Ryu MJ. Efficacy of cosmetic materials using Aronia melanocarpa leaf extracts. Asian Journal of Beauty and Cosmetology, 16: 179-190, 2018.

Lim GO, Jang SA, Kim JL, Kim HJ, Song KB. Use of felatin film containing grapefruit seed extract in the packaging of strawberries. Korean Journal of Food Preservation, 17: 196-201, 2010.

Ryu JY, Rhie SJ, Lim KH, Choi YE, Han HS, Yang HO, Na EJ. Inhibitory effects of prunin on photo-aging in human keratinocytes (HaCaT) damaged by UVB radiation. Asian Journal of Beauty and Cosmetology, 17: 139-147, 2019.

Shin JH, Seo SR. Anti-inflammatory activity of Eurya persicifolia Gagnep. extract in Propionibacterium acnes- 
induced inflammatory signaling by regulation of NF-KB activity. Korean Journal of Microbiology, 55: 213-219, 2019.

Sripathi SK, Lalitha P. Keratolytic molecule aided inhibition of DNA damage and tyrosinase activity of a herbal formulation. International Journal of BioSciences and Technology, 9: 7-14, 2016.

Skobe M, Detmar D. Structure, function, and molecular control of the skin lymphatic system. Journal of Investigative Dermatology Symposium Proceedings, 5: 14-19, 2000.

Takenokuchi M, Kadoyama K, Yoshida D, Takaki S, Yamamoto $\mathrm{R}$, Saigo K, Taniguchi T. Evaluation of absorbability of macromolecular substances in the oral mucosa and skin using a three-dimensional tissue culture model. Biology and Medicine, 10: 1000448, 2018.
Talwar HS, Griffiths CE, Fisher GJ, Hamilton TA, Voorhees JJ. Reduced type I and type III procollagens in photodamaged adult human skin. Journal of Investigative Dermatology, 105: 285-290, 1995.

Waller JM, Maibach HI. Age and skin structure and function, a quantitative approach (II): protein, glycosaminoglycan, water, and lipid content and structure. Skin Research and Technology, 12: 145-154, 2006.

Zhang H, Pan D, Dong Y, Su W, Su H, Wei X, Yang C, Jing L, Tang X, Li X, Zhao D, Sun L, Qi B. Transdermal permeation effect of collagen hydrolysates of deer sinew on mouse skin, ex vitro, and antioxidant activity, increased type I collagen secretion of percutaneous proteins in NIH/3T3 cells. Journal of Cosmetic Dermatology, 19: 519-528, 2020. 


\section{국문초록}

\section{저분자 콜라겐을 이용한 천연추출복합물 함유 구강붕해필름의 개발과 향장기능성 연구}

김동섭, 한인준, 이병수, 박상윤, 노은영, 엄지, 서지영, 김건, 박지현, 성낙윤*

한국프라임제약주식회사 천연물연구부, 광주, 한국

목적: 본 연구는 저분자콜라겐과 천연추출복합물을 이용한 구강용해필름(이너뷰티필름)을 개발하여 in vitro 실험과 인체적용시험을 통하여 향장기능성을 검증하고자 한다. 방법: 이너뷰티필름의 피부세포에서의 독성 및 procollagen생성능, elastase 및 collagenase 억제능, $\mathrm{DPPH}$ 라디칼 소거능, tyrosinase 억제능을 측정하여 시험관시험 및 인체적용시험을 통해 피부개선 효과를 검증하였다. 결 과: 저분자콜라겐과 천연추출복합물의 혼합에 의한 피부세포독성을 확인한 결과 $1000 \mu \mathrm{g} / \mathrm{mL}$ 까지 독성은 확인할 수 없었으며 주름 개선의 지표인 elastase는 $125 \mu \mathrm{g} / \mathrm{mL}$ 이상 농도에서 $7.2 \%$ 의 효과를 나타내었으며 collagenase는 $31.3 \mu \mathrm{g} / \mathrm{mL}$ 이상에서 $16.3 \%$ 의 억 제 효율을 나타내었다. 피부세포를 이용한 procollagen생성은 $62.5 \mu \mathrm{g} / \mathrm{mL}$ 이상일 때 음성대조군 대비 $34 \%$ 의 유의적인 생성효과를 보였다. 항산화 활성은 $250 \mu \mathrm{g} / \mathrm{mL}$, 미백은 $62.5 \mu \mathrm{g} / \mathrm{mL}$ 이상 함유되었을 때 유의적인 효과가 확인되었고 6개월간 안정성확인에서도 변형이나 색도변화는 없었다. 인체적용시험에서도 이너뷰티필름의 사용 전과 후의 주름개선은 최대 $32.2 \%$, 색소잡티개선은 $32.5 \%$, 모공수축은 $31.5 \%$ 그리고 피부치밀도의 개선에서 $12.8 \%$ 의 유의미한 결과를 확인하였다. 결론: 저분자 콜라겐 및 천연추출복합물이 함유된 이너뷰티필름은 주름개선, 색소잡티개선, 모공수축, 피부치밀도개선 및 항산화, 미백에 효과가 있는 것으로 확인되어 먹는 화장품 및 식품으로 개발이 가능한 것으로 사료된다.

핵심어: 이너뷰티필름, 주름개선, 미백, 기능성화장품, 저분자콜라겐

\section{참고문헌}

강학희. 화장품과 피부노화. 대한화장품학회지, $23: 57-73,1997$.

김영숙, 정은영, 고혜정, 홍양희. 마늘추출물 함유 화장료의 피부 기능성 효과: 항산화 및 콜라게나제, 엘라스타제와 티로시나

제의 억제 효과를 중심으로. 아시안뷰티화장품학술지, 13: 469-476, 2015.

김정기, 이지해, 배일홍, 서대방, 이상준. 콜라겐 펩타이드의 피부 장벽 보호 효과. 한국식품과학학회지, 43: 458-463, 2011. 김호원, 김동섭, 성낙윤, 한인준, 이병수, 박상윤, 엄지, 서지영, 박지현, 유아름, 김종석. 비타민나무열매, 블랙베리잎과 약용

들깨잎의 추출물 복합제를 이용한 복합 기능성 화장품 소재 개발. 아시안뷰티화장품학술지, 17: 477-488, 2019.

류지영, 이승자, 임계화, 최영은, 한효선, 양현옥, 나은주. Prunin의 자외선 B에 의해 손상된 인간 각질형성세포(HaCaT)에 대

한 광노화 억제 효과. 아시안뷰티화장품학술지, 17: 139-147, 2019.

신진학, 서수련. Propionibacterium acnes에 의한 염증반응에서 Eurya persicifolia Gagnep. 추출물의 억제효과. 미생물학회

지, 55: 213-219, 2019.

이정민, 류민정. 아로니아 잎 추출물을 이용한 화장품 소재 개발. 아시안뷰티화장품학술지, 16: 179-190, 2018.

임금옥, 장성애, 김주연, 김현진, 송경빈. 자몽종자 추출물을 함유한 젤라틴 필름의 딸기에의 포장 적용. 한국식품저장유통학

회지, 14: 196-201, 2010.

정향숙, 권민철, 한재건, 하지혜, 김 령, 김진철, 곽형근, 황보영, 이현용. 불가사리 유래 콜라겐 펩타이드의 피부 면역 증진 효

과. 한국식품과학학회지, $40: 522-527,2008$.

정형식, 장현상, 조영호, 이계원. 불용성 미립자를 이용한 천문동 추출물 함유 분산형 구강붕해필름 개발. KSBB Journal, 34 :

159-166, 2019.

한상국, 김희택, 김용민, 박성민, 이정노, 오성화, 하헌용. 3 종 천연물 혼합 추출물의 피부 진피치밀도 개선 효과. 대한미용학

회지, 12: 221-225, 2016. 


\section{中文摘要}

\section{多肽胶原口腔崩解膜的研制及其功能}

金東䛓，韓仁準，李秉洙，朴相玧，盧恩映，嚴智，徐至永，金乾，朴智賢，成樂倫

Korea Prime Pharm有限公司天然物研究所，光州，韩国

目的: 通过体外实验和人体应用试验，研究多肽胶原和天然衍生化合物的多效性。方法：通过体外和人体应用试 验, 测定内美容膜（IBF）的细胞毒性、促胶原蛋白生成能力、弹性蛋白酶和胶原酶抑制能力、DPPH自由基清 除能力和酪氨酸酶抑制能力以及皮肤改善情况。结果: 浓度达到 $1000 \mu \mathrm{g} / \mathrm{mL}$ 为止, 不显示细胞毒性 ; 浓度为 125 $\mu \mathrm{g} / \mathrm{mL}$ 时, 弹性蛋白酶抑制率为 $7.2 \%$; 浓度为 $31.3 \mu \mathrm{g} / \mathrm{mL}$ 时, 胶原酶抑制率为 $16.3 \%$, 而 $62.5 \mu \mathrm{g} / \mathrm{mL}$ 时, 与 阴性对照组相比, 前胶原合成表达为 $34 \%$, 具有统计性意义。抗氧化活性在 $250 \mu \mathrm{g} / \mathrm{mL}$, 美白效果在 $62.5 \mu \mathrm{g} /$ $\mathrm{mL}$ 以上时, 确认了显著效果, 经6个月的稳定性验证, 均未出现变形或变色现象。即使在人类临床研究中, 使 用IBF前后的皱纹改善率最高为 $32.2 \%$, 皮肤黑色素和褐斑改善率为 $32.5 \%$, 毛孔改善率为 $31.5 \%$, 皮肤密度改 善率为 $12.8 \%$ ，都具有显著效果。结论：含多肽胶原复合物和天然衍生化合物的IBF对改善皱纹、改善皮肤黑色 素和褐玟、改善皮肤毛孔、改善皮肤密度有积极作用, 并具有抗氧化和美白作用。因此, IBF可以作为化妆品和 食品的关键材料。

关键词: 内美容膜, 抗皱, 美白, 功能性化妆品, 肽胶原蛋白 
